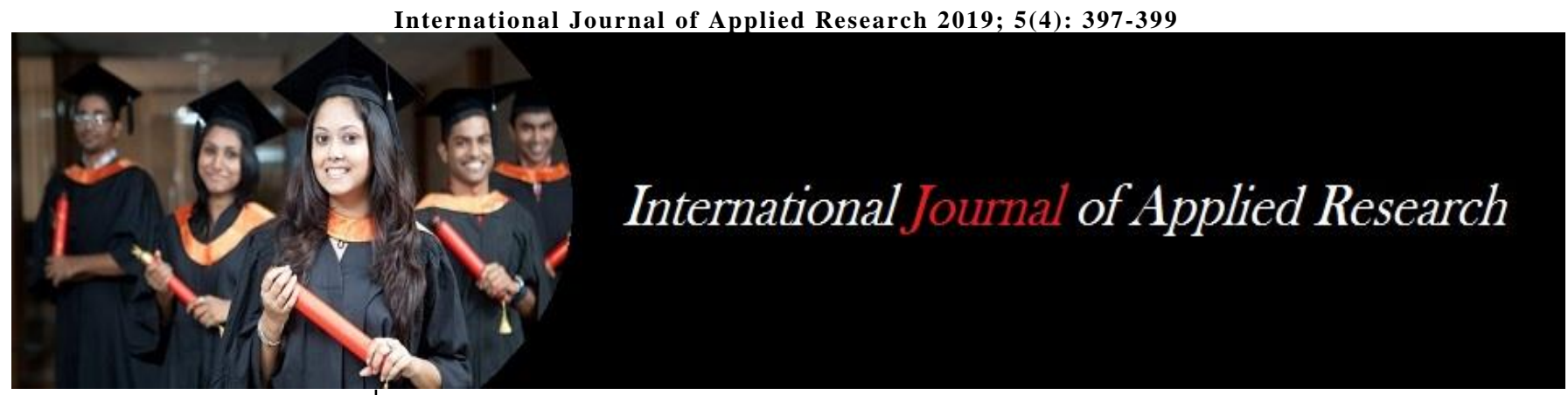

ISSN Print: 2394-7500 ISSN Online: 2394-5869 Impact Factor: 5.2

IJAR 2019; 5(4): 397-399 www.allresearchjournal.com Received: 01-02-2019 Accepted: 02-03-2019

Dr. Shankar Chatterjee Former Professor\& Head (CPME) NIRD \&PR (Govt. of India), Hyderabad, Telangana India
Correspondence

Dr. Shankar Chatterjee

Former Professor\& Head (CPME) NIRD \&PR (Govt. of India), Hyderabad, Telangana, India

\section{Economic improvement of rural households based on backward and forward linkages: A study at Aurangabad district of Maharashtra}

\section{Dr. Shankar Chatterjee}

\section{Abstract}

This study reveals that if income generation project is prepared based on Backward and Forward Linkages then undoubtedly income of the rural below poverty line (BPL) households will improve. Based on the study carried out at Aurangabad District of Maharashtra in the Month of March 2019 a case has been presented here. One SHG along with their few members were contacted to get an idea about the functioning of self-help group (SHG) in the district as well as earning (income) of members after joining in the SHG. The SHG was part of earlier Swarna Jayanthi Gram Swarojgar Yojana (SGSY), a self-employment scheme sponsored by the Ministry of Rural Development, Government of India. In view of this, few lines about SGSY are presented here for the benefit of readers. So, the study is based on both primary and secondary data.

Keywords: Aurangabad, backward and forward linkages, income, self-help groups (SHGs) and SGSY

\section{Introduction}

Unemployment and rural poverty are major issues in every country. Even developed countries cannot provide job to all, so the alternative is self-employment. Muhammad Yunus, the Nobel laureate, in his book Banker to the Poor has highlighted some advantages of selfemployment over wage employment.

1 The hours are flexible and can adapt to fit any family situation. It allows people to choose between running a business full-time or part-time when they need to meet crises, or to put their business on hold and work full-time for a salary.

2 Self-employment is tailor-made for anyone who is street-smart and has many acquired from books and technical schools. This means the illiterate and the poor can exploit their strengths, rather than be held back by their weaknesses

3 It allows a person to turn hobbies they enjoy into gainful employment.

4 It allows individuals who cannot work well in a rigid hierarchy to run their own show.

5 It offers a way out of welfare dependency, not just to become wage slaves, but to open a store or start a manufacturing business.

6 It can help those who have found a job and are still nonetheless poor.

7 It gives those who have just been fired from a job moral support to start a business before they become depressed and isolated.

8 It gives the victims of prejudice who would not be hired because of their colour or national origin a chance to earn a living. The average cost of creating a self-employment job is ten, twenty or hundred times cheaper than creating an employment job.

9 It helps isolated poor person gain self-confidence, step by step.

To generate self-employment in the rural areas during 1980s and also in 1990s different selfemployment programmes were introduced in India. These were Integrated Rural Development Programme (IRDP), Development of Women and Children in Rural Areas (DWCRA), Training of Rural Youth for Self-Employment (TRYSEM), Supply of Improved Toolkits for Rural Artisans (SITRA), Million Wells Scheme (MWS) and Ganga Kalyan Yojana (GKY). Later on in 1999, $1^{\text {st }}$ April all these self-employment programmes were merged into one i.e. Swarnajayanthi Gram Swarojgar Yojana (SGSY) and again from June 2011, a new Programme namely National Rural Livelihoods Mission (NRLM, now known as 
DAY-NRLM, Deendayal Antyodaya Yojana-NRLM) has been introduced in all the rural areas after restructuring SGSY by the Ministry of Rural Development, Government of India. DAY-NRLM has set out with an agenda to cover 7 Crore BPL households, across 600 districts, 6000 blocks, 2.5 lakh Gram Panchayats and 6 lakh villages in the country through self-managed Self-Help Groups (SHGs) and federated institutions and support them for livelihoods collectives in a period of 8-10 years. In addition, the poor would be facilitated to achieve increased access to their rights, entitlements and public services, diversified risk and better social indicators of empowerment. DAY-NRLM believes in harnessing the innate capabilities of the poor and complements them with capacities (information, knowledge, skills, tools, finance and collectivization) to participate in the growing economy of the country (www.aajeevika.gov.in). Since in this research article case has been presented on SGSY so achievement of SGSY since to 2012-13 are presented. It is pertinent to mention that because of financial reason SGSY data were available up to 2012-13 (end of SGSY), albeit DAY-NRLM was introduced in June 2011 by restructuring SGSY.

Table 1: Progress of SGSY from 1999-2000 to 2012-13 (Financial Progress Rs. in Crore \& Physical Progress in Number)

\begin{tabular}{|c|c|}
\hline Items & Total/Average \\
\hline Funds Available & 27904.58 \\
\hline Funds Utilized & 21219.23 \\
\hline \%age utilization to funds available & 76.04 \\
\hline Total Credit Mobilised & 31826.91 \\
\hline Credit Disbursed to SHGs & 21435.98 \\
\hline Credit Disbursed to Individual Swarozgaris & 10390.94 \\
\hline Total Subsidy Disbursed & 14446.63 \\
\hline Total Investment & 46273.55 \\
\hline Credit Subsidy Ratio & 2.13 \\
\hline Self-Help Groups formed & 4334544 \\
\hline Women SHGs formed & 2951803 \\
\hline \%age of Women SHGs & 68.1 \\
\hline SHGs taken up Eco. Activities -Achievement & 1445800 \\
\hline SHGs Swarozgaris Assisted - Achievement & 12730503 \\
\hline Individual Swarozgaris Assisted & 4729619 \\
\hline Swarozgaris assisted under Special Project & 532948 \\
\hline Total Swarozgaris Assisted Achievement & 17993070 \\
\hline \%age of SC/STs Assisted & 47.27 \\
\hline \%age of Minorities assisted & 11.12 \\
\hline \%age of Women Assisted & 60.59 \\
\hline \%age of Disabled Assisted & 1.58 \\
\hline
\end{tabular}

Source: data.gov.in/catalog/physical-and-financial-progress-underswarnjayanti-gram-swarozgar-yojana-sgsy/4th $A$ thil 2019.

\section{The important points as observed from the above table are}

- Percentage of Women SHGs was 68.1 which is a praiseworthy achievement.

- Percentage of Women SHGs assisted was around 61.0 which is a laudable point as according to guidelines it should be minimum of 40 per cent.

- Percentage of SC/STs assisted was 47.0, little less than 50 percent as envisaged in the guidelines.

- In case of SGSY there was provision for individual person but the same has been discarded in DAYNRLM.

Study Area and Methodology

To get an idea about the functioning of sustainable SHG, the study was conducted at Bhadji village, Khultabad block of Aurangabad district in the month of March 2019 by contacting the members of Self-Help Group (SHG). So, the study is based on both primary and secondary data. All the members participated in the discussion as PRA method and as tool Group Discussion was carried out. It is pertinent to mention that PRA methodology earlier used to known as Participatory Rural Appraisal, (now PRA is used), has been introduced by Robert Chambers. According to him, "PRA is a growing family of approaches and methods to enable local people to share, enhance and analyse their knowledge of life and conditions and to plan, act, monitor and evaluate. PRA approaches and methods present alternatives to questionnaire surveys in appraisal and research and generate insights of policy relevance." PRA helps in generating different kind of data, identifying and mobilizing intended groups for decision making, project design, implementation, monitoring and evaluation. In PRA, "outsiders do not dominate and lecture; they facilitate, sit down, listen and learn.

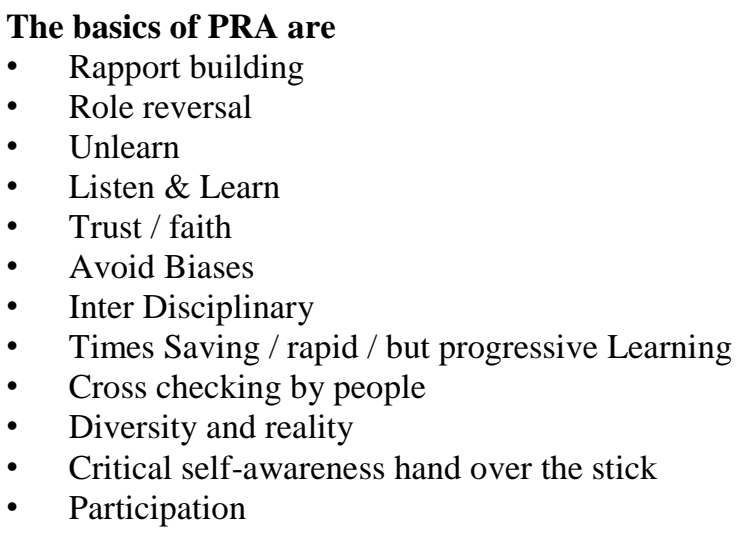

\section{Study findings}

Rani Laxmibai SHG was formed by 10 women of SC, OBC and other caste persons in the month of September 2014 at Bhadji village, Khultabad block of Aurangabad district. Each member was saving @ Rs.100 per month. Based on Backward and Forward linkages the group members started sweet making items (locally known as Chikki). The main ingredient is jaggery and other ingredients used by them are peanut, sesame (til), coconut and rajgira (a grain also known as Ramdana). For one preparation one item is used, e.g. when peanut is used other products are not mixed with peanut and thus the production process continues. At the time of selling of the product, name is used before 'Chikki' e.g. 'coconut-chikki', til-chikki etc.

During the course of study, it was observed that the members of the SHG were producing these locally as all the raw-materials were available as well as marketing facility indicating favourable 'Backward' and 'Forward' linkages. Regarding Forward Linkage it may be mentioned here that, they had good market as nearby one temple is located where the SHG by paying monthly rent of Rs. 2,000.00 hired a stall. The SHG had three more stalls - one at Elllora and two at Aurangabad city. By paying monthly rent of Rs. 500.00 for each stall, they manage the business. During the course of discussion, the members informed that the SHG was extended revolving fund (RF) of Rs. 15,000.00 and Cash Credit Limit (CCL) of Rs. 50,000.00, because this SHG was under the umbrella of SGSY which continued that time sponsored by the Ministry of Rural Development, 
Government of India. It is pertinent to mention that under SGSY, each SHG which was in existence at least for a period of six months and which demonstrated the potential of viable group was provided revolving fund (one time assistance given by the Government through District Rural Development Agency, DRDA) and cash credit limit (CCL) from the bank which was a type of loan.

After extending the RF and CCL, the SHG was given a sum of Rs.1.50 lakh as loan which they repaid within the stipulated time. Again, a sum of Rs.3.00 lakh as bank loan was given to the SHG (during the time of study, March 2019 loan repayment was going on for Rs 3 lakh). The members informed that in the village one male person Sri Dhansingh Pushe worked in a 'chikki' factory and decided to help his village women. Accordingly, he organized them in a SHG and trained them and thus SHG started the business under his guidance. The Group Discussion with the members revealed that during the process of production, no machine was used as all activities were carried out by hand in a hygienic way and after that they make the packets by hand also and sell. Further, all the members in unison informed that individually they earn in the range of Rs. 15,000.00 to Rs. 28,000.00 per month which was in addition to their husband's earning (except one case). Individually five cases are presented here.

Case -1: Mrs. Sumanbai Ambe (50 years $/ 4^{\text {th }}$ pass/ OBC) with five children (4 sons \&1 daughter) had to suffer economically before joining SHG because husband was working as carpenter earning meager income and the family did not have any agricultural land. After joining the SHG, she felt empowered as support of nine SHG members was with her. She borrowed three times from SHG's corpus fund - Rs. 30,000.00, Rs. 20,000.00 and Rs. 10,000.00. By borrowing the amounts, she utilized for development of the family, such as marriage of the children (3 sons+1 daughter \& 1 son did not marry that time), house renovation etc. After marriage, three sons were staying separately but the unmarried son (with disability and graduate) started imitation jewellery shop in the village. Mrs. Sumanbai in addition to making 'chikki' sweet also involved in tailoring as she purchased one tailoring machine. She informed that her average income per month was Rs. 18,000.00.

Case 2: Mrs. Babybai Ambe (45 years/ $7^{\text {th }}$ pass/ OBC) with two children ( 1 son +1 daughter) had tough time once upon a time as the family had no agricultural land and husband's earning was not adequate as he has physical problem, although working as carpenter. Mrs. Babybai after joining the SHG borrowed four times- Rs. 30,000.00, Rs. 20, 000.00, Rs. 10,000.00 (two times). With these amounts, she purchased one tailoring machine and started a petty shop where chocolates, biscuits etc., are sold (in her house). Also, with loan money, she arranged marriage of her son and daughter. The son was working in other area so staying separately with his wife. Mrs. Babybai was earning on an average Rs. 17,000.00 per month by making 'chikki and also earning little from tailoring.

Case 3: Mrs. Mongal Wakale (42 years/ $8^{\text {th }}$ pass / other caste) with three children (1 son +2 daughters, one daughter married) managing family with two acres of agricultural land as both in Kharif and Rabi crops are grown. She borrowed from SHG's corpus fund three times - Rs.
30,000.00, Rs. 20,000.00 and Rs. 10,000.00. With these loan amounts, in addition to development of agriculture, she purchased one jersey cow. Her total earning was around Rs. $18,000.00$ per month, albeit it is not easy to calculate income of the persons having agricultural land but with discussion as well as with her own idea, the conclusion about earning of income was derived.

Case 4: Mrs. Lilabai Pushe (50 years/SC/ illiterate) with five children ( 3 sons and two daughters, except one son all married) had to work as agricultural labour in the village and its vicinity as husband because of health problem cannot work. She borrowed three times Rs. 30,000.00, Rs. 20,000.00 and Rs. 10,000.00 from SHG's corpus fund and utilized the total amount of Rs. 60,000.00 for the development of the family and also purchased one tailoring machine for enhancing income. In addition to making 'chikki', she was also earning through tailoring and her total earning was around Rs. 15,000.00 per month.

Case 5: Mrs. Ratna Pushe (28/7 $7^{\text {th }}$ pass/ SC) with two sons (school going) and no agricultural land was eking out their livelihoods by making 'chikki'. As mentioned already, Sri Dhansingh Pushe, who introduced 'chikki' making in the village with women members, is her husband. At the time of study, both Mrs. Ratna Pushe and husband Sri Dhansingh Pushe along with SHG members were present and all informed that Sri Pushe was taking care of full marketing aspects with the consent of all other SHG members as he had knowledge in this regard. Mrs. Ratna Pushe borrowed three times from SHG- Rs. 30,000.00, Rs. 20,000.00 and Rs. $10,000.00$. Earning of both husband and wife was hovering around Rs. 28,000.00 per month.

\section{Conclusion}

The field-based study glaringly reveals that by forming SHG and making 'chikki' and subsequently borrowing from SHG's Corpus fund, women members including their family have been greatly benefitted as both Backward and Forward linkages were favourable. In addition, knowledge of local male person about 'chikki' making facilitated the group to sustain. It may be mentioned here that study was carried out five years after formation of the SHG so sustainability can be accepted. Further, it is heartening to mention that SHG consisted of different castes and activities were carried out without any hassle.

(The author extends his grateful thanks to the Project Director, DRDA, Aurangabad and his staffs for their cooperation in carrying out the study).

\section{References}

1 https://aajeevika.gov.in/content/welcome-deendayalantyodaya-yojana-nrlm/1st April 2019.

2 Yunus Muhammad Banker to the poor; the story of the Grameen Bank, Published by Penguin Books, 2007.

3 Robert Chambers, Whose Reality Counts? Putting the first last Intermediate Technology Publications, London, 1997. 